\title{
CLINICAL AND EPIDEMIOLOGICAL CHARACTERISTICS OF CUTANEOUS LEISHMANIASIS CASES IN ISTANBUL
}

\author{
İstanbul'daki kutanöz layşmanyazis olgularının klinik ve \\ epidemiyolojik özellikleri
}

\author{
Neşe YAKŞi1 ${ }^{\circledR}$, Hatice IKIIIŞIK ${ }^{\circledR}$, Abdullah Emre GÜNER ${ }^{3}$, Işıl MARAL ${ }^{2}$
}

\begin{abstract}
Cutaneous leishmaniasis $(\mathrm{CL})$ is a vector-borne disease characterized by skin lesions healing with an atrophic scar. Istanbul is a high risk province for $\mathrm{CL}$ due to internal and international immigrants. The aim of this study is to determine the clinical and epidemiological characteristics of CL cases in Istanbul. In this descriptive study, we evaluated the Cutaneous leishmaniasis cases in Istanbul between June 1st, 2014 and May 31st, 2015. The ethics committee and instutional permissions were received. Frequency analysis were used for data analysis. The study was carried out with $197 \mathrm{CL}$ cases. Percentage of patients under 18 years old was $52 \%$. Seventy seven percent of cases were Syrian and most of them had no passports. Household avarage number was six. Percentage of individuals with a CL lesion at household in the last year was $23 \%$. Sixteen percent of cases reported a recent visit to Southeastern Anatolia and $55 \%$ of them reported that the lesions appeared after the visit. About half of cases had more than one lesion. Face (43.7\%) was the most commonly affected. The lesions of 74 cases (38\%) appeared before living in Istanbul. Health Directorates of the districts where Syrian immigrants live in Istanbul should screen Syrian immigrants in terms of CL periodically. Also improving living conditions, drying of stagnant water areas, use of mosquito nets, wearing long-sleeved clothes, diagnosis and effective treatment of $C L$ are recommended methods for $C L$ control.
\end{abstract}

Keywords: Cutaneous leishmaniasis, Syrian immigrants, epidemiology, Istanbul.

\section{Özet}

Kutanöz layşmanyazis $(\mathrm{KL})$, atrofik skarla iyileşen cilt lezyonları ile karakterize vektörel bir hastalıktır. Türkiye ve Suriye KL'nin endemik olduğu 98 ülke arasında yer almaktadır. Istanbul ise hem dış hem de iç göç nedeniyle KL açısından yüksek riskli bir ilimizdir. Bu çalışmanın amacı Istanbul'daki KL olgularının klinik ve epidemiyolojik özelliklerini belirlemektir. Tanımlayıcı tipteki bu çalışmada, 1 Haziran 2014 - 31 Mayıs 2015 tarihleri arasında Istanbul'daki Kutanöz layşmanyazis olguları değerlendirilmiştir. Araştırma etik kurul ve kurum izni alınmıştır. Veri analizi için frekans analizi kullanılmıştır. Çalışma $197 \mathrm{KL}$ olgusu ile gerçekleştirilmiştir. On sekiz yaşın altındaki hastaların yüzdesi \%52'dir. Olguların \%93'ü ortalama yedi aydır Istanbul'da ikamet etmektedir. Olguların \%77'sinin Suriyelidir ve çoğunun pasaportu bulunmamaktadır. Hane halkı ortalama sayısı altıdır. Olguların \%23'ünde son bir yılda hanesinde KL lezyonu olan birey olduğunu ifade etmiştir. Olguların \%16'sı yakın zamanda Güneydoğu Anadolu Bölgesi'ne ziyareti olduğunu ve \%55'i lezyonların bu ziyaretten sonra ortaya çıktığını bildirmiştir. Olguların yaklaşık yarısında birden fazla lezyon vardır ve lezyonların \%44'ünün yüz bölgesindedir. Yetmiş dört olgunun lezyonları (\%38) Istanbul'da yaşamaya başlamadan önce ortaya çıkmıştır. Suriyeli misafirler Istanbul'da yaşadığı ilçelerde İlçe Sağıı Müdürlükleri tarafından $\mathrm{KL}$ açısından düzenli olarak taranmalıdır. Ayrıca yaşam koşullarının iyileştirilmesi, durgun su alanlarının kurutulması, cibinlik kullanılması, uzun kollu kıyafetler giyilmesi, KL'nin erken teşhis ve etkili tedavisi KL kontrolü için önerilmektedir. Anahtar kelimeler: Kutanöz layşmanyazis, Suriyeli göçmenler, epidemiyoloji, Istanbul.

1- Nigde Community Health Center, Nigde Provincial Health Directorate, Nigde, Turkey

2- Department of Public Health, School of Medicine, Istanbul Medeniyet University, Istanbul, Turkey

3- Public Health Services Department, Istanbul Provincial Health Directorate, Istanbul, Turkey

Sorumlu Yazar / Corresponding Author: Uzm. Dr. Neşe YAKŞI

e-posta / e-mail: drnsyks@gmail.com

Geliş tarihi / Received: 15.03.2021, Kabul Tarihi / Accepted: 29.07.2021

ORCID: Neşe YAKŞI

: 0000-0002-6175-2359

Hatice IKIIIŞIK

0000-0003-0958-0649

Abdullah Emre GÜNER : :0000-0001-8624-4468

Işı MARAL

: 0000-0001-5234-6108

Nasıl Atıf Yaparım / How to Cite: Yaksi N, Ikiisik H, Güner AE, Maral I. Clinical and epidemiological characteristics of Cutaneous leishmaniasis cases in Istanbul. ESTUDAM Public Health Journal. 2021;6(3):209-15. 


\section{Introduction}

Leishmaniasis is a vector-borne disease transmitted by female sand flies (Phlebotomus) infected with Leishmania parasite especially in summer months. Leishmaniasis is evaluated in three groups as visceral, cutaneous and mucocutaneous and the most common form is Cutaneous leishmaniasis (CL). This form is characterized by skin lesions usually on uncovered parts of body such as face, hand, arm, leg and rarely on mucosal surfaces. These lesions heal by treatment or spontaneously leaving an atrophic scar and life-long immunity (1).

Leishmaniasis, which is endemic in approximately 98 countries, has been reported as the second most important disease after malaria in the list of six important tropical diseases determined by World Health Organization (WHO). According to $\mathrm{WHO}$ data, it is estimated that there are two million new cases $(0.5$ million Visceral leishmaniasis, 1.5 million Cutaneous leishmaniasis) per year (2). Ninety four percent of leishmania cases in the world are observed in Brazil, Ethiopia, India, Kenya, Somalia, South Sudan and Sudan. More than $90 \%$ of CL cases are seen in Afghanistan, Pakistan and Syria (3). The number of CL cases in Syria was 50.000 in 2015 with an incidence rate of 32/10000. Incidence rate was higher especially in regions close to Turkey such as Halep and Hasici (4). According to Turkey data of WHO Leishmania Report 2016; CL is endemic in Turkey and cases are reported especially in Southeast Anatolia and Mediterranean Region. About half of CL cases in Turkey are reported from Sanliurfa province and the number of cases exhibit a varying trend year by year. The number of CL cases peaked in 2004, 2010 and increased 2.5 times (to

\section{Material-Method}

"Cutaneous Leishmaniasis Notification Form" was developed by the researchers to evaluate $\mathrm{CL}$ survellience in Istanbul by researchers. It was used to evaluate sociodemographic characteristics, disease
5000) in 2013 compared to the previous year. The number of cases was 2563 in 2016 with incidence rate of $0.62 / 10000$ while 3000 case were reported in 2015 . About $43 \%$ of cases were reported as imported cases in 2016 (5).

The Turkish Ministry of Health made a plan to combat CL in Turkey in 1996 with a title "Cutaneous Leishmaniasis Control Program". Since 2004, drugs have been given to patients free of charge. In addition, $\mathrm{CL}$ is a notifiable disease and if $\mathrm{CL}$ is diagnosed by any private or state health centers, treatment should be started and patient information must be reported to Provincial Health Directorate (6).

Population shift from rural to urban areas due to travel, migration, working etc. increased over the years, however inadequate infrastructure and unhealthy housing conditions lead to the spread of diseases in cities. It should be kept in mind that the Syrian citizens who migrated to Turkey as a result of the war that has been going on since 2011 in Syria might also be transporting and spreading some infectious diseases such as CL. The number of Syrians with temporary protected status, which was 300,000 in 2013, was 2.5 million in 2015 and approximately 3.7 million in 2019. High number of Syrian immigrants who came from CL-endemic areas for long years, local Turkish population migrated mostly from provinces with high $\mathrm{CL}$ incidence to Istanbul, which is a crossing point for Europe, can be considered among the factors increasing the number of $\mathrm{CL}$ cases in Istanbul.

The aim of this study is to determine the clinical and epidemiological characteristics of $\mathrm{CL}$ cases in Istanbul between the dates of June 1st, 2014 and May 31st, 2015.

characteristics and epidemiological risk factors. For this descriptive study we evaluated all notification forms of Provincial Health Directorate between June 1st, 2014 and May 31st, 2015. Sample selection was 
not used. The forms were completed by a staff of communicable diseases unit of Istanbul Provincial Health Directorate who could speak Arabic and Kurdish after the interviews with patients or their relatives. The ethics committee permission and instutional permission was received. The Ethical (2015/0123) permissions was received from Istanbul Medeniyet University Goztepe Training and Research Hospital Clinical

\section{Results}

The study was carried out with 197 CL cases in Istanbul between June 1st, 2014 and May 31st, 2015 in Istanbul. Forty seven percent of the cases were female and median age was 16 (min: 1 max: 74). Percentage of patients under 18 years old was $52 \%$. Of the cases, 114 were single $(58 \%)$ and 51 were married (26\%). In sixty three cases $(32 \%)$ the person who has the disease was interviewed. In others, fathers $(20 \%)$, mothers $(14 \%)$ and spouses $(4 \%)$ were interviewed (Table 1).

One hundred and eighty three cases $(93 \%)$ resided in Istanbul, while one case was
Research Ethics Committee at the date of 09.09.2015.

\section{Statistical analysis}

IBM SPSS Statistics Standart 22 Version program (Analytical Information Management Solutions (AIMS), Istanbul, Turkey) was used for data analysis. Frequency and percentage values were used as statistical analysis.

in Bulgaria, one case in Mardin and two cases in Mus. The median duration for residence in Istanbul was seven months (min: 1 max: 297 months). Most of the residents in Istanbul (90\%) lived in the European side and the highest number of cases were observed in Bagcilar (15\%), Esenyurt (8.1\%), Bahcelievler $(8.1 \%)$ and Zeytinburnu $(7.6 \%)$ districts. One hundred fifty two cases $(77 \%)$ were Syrian and 34 $(17 \%)$ were Turkish. Only $28(18 \%)$ of the Syrian cases had passports and 86 (57\%) were without one (Table 1).

Tablo 1: Sociodemografic characteristics of cases.

\begin{tabular}{|c|c|c|}
\hline Sociodemografic characteristics & $\mathbf{n}$ & $\%$ \\
\hline \multicolumn{3}{|l|}{ Age $(n=188)$} \\
\hline $18>$ & 98 & 52.0 \\
\hline $18 \leq$ & 90 & 48.0 \\
\hline \multicolumn{3}{|l|}{$\operatorname{Sex}(n=190)$} \\
\hline Female & 90 & 47.0 \\
\hline Male & 100 & 53.0 \\
\hline \multicolumn{3}{|l|}{ Interviewed person $(n=197)$} \\
\hline Mother-father & 66 & 34.0 \\
\hline Itself & 63 & 32.0 \\
\hline Others & 68 & 34.0 \\
\hline \multicolumn{3}{|l|}{ Residence in Istanbul ( $n=197)$} \\
\hline Yes & 183 & 93.0 \\
\hline No & 9 & 5.0 \\
\hline Unspecified & 5 & 2.0 \\
\hline \multicolumn{3}{|l|}{ Residence in Istanbul ( $n=183)$} \\
\hline Anatolia & 17 & 10.0 \\
\hline Europe & 164 & 90.0 \\
\hline \multicolumn{3}{|l|}{ Citizenship status ( $n=197$ ) } \\
\hline Unspecified & 10 & 5.1 \\
\hline Cyprus & 1 & 0.5 \\
\hline Syria & 152 & 77.2 \\
\hline Turkey & 34 & 17.2 \\
\hline \multicolumn{3}{|l|}{ Passport status of Syrians ( $n=152)$} \\
\hline Present & 28 & 18.0 \\
\hline Non-present & 86 & 57.0 \\
\hline Unspecified & 38 & 25.0 \\
\hline
\end{tabular}


One hundred thirteen cases $(57 \%)$ resided in apartments and six cases (3\%) lived in the slums. Wetlands existed around residential areas in $2.4 \%$ of the cases and in $3 \%$ of them there were animal shelters around the residential areas (Table 2). The median value of the number of people living at the same household with a patient was 6 (min: 1 max: 30). Percentage of individuals with a CL lesion at same household in the last year was $23 \%$ (45) and the ratio of being living in the same household with a CL scar was $4.6 \%$ (9). Thirty-one cases (16\%) reported a recent visit to one or more provinces in Southeastern Anatolia Region (Table 2) including Mersin, Batman, Bitlis, Çorum, Diyarbakir, Elazıg, Amasya, Muş, Hatay, Iraq, Kilis, Kahramanmaraş, Mardin, Osmaniye, Gaziantep, Sanlıurfa, Siirt, Tokat and Van. One hundred and fifty cases $(76 \%)$ had first CL treatment. While 67 cases (53\%) had one lesion, 60 cases $(47 \%)$ had more than one lesion. Face (43.7\%), arm (12.7\%), hand $(11.7 \%)$ were the most common body parts where lesions appeared (Table 2).

The lesions of 74 cases (38\%) appeared before they started to live in Istanbul, whereas 71 cases (36\%) appeared after they started to live in Istanbul (Table 2). The average time between starting to live in Istanbul and appearing of lesions was six months (min: 0,03 max: 293). Seventeen $(55 \%)$ of the 31 cases with a recent visit to Southeastern Anatolia Region reported that the lesions appeared at a later date of the visit (Table 2). The median time between lesions appeared and diagnosis were 181 days (min: 0 max:2583). The percentage of chronic CL (lesion duration of more than 24 months) was $3.6 \%$.

Tablo 2: Clinical and epidemiological factors of cases.

\begin{tabular}{|c|c|c|}
\hline Factors & $\mathbf{n}$ & $\%$ \\
\hline \multicolumn{3}{|c|}{ Body part of lesion appeared $(n=197)$} \\
\hline Foot & 9 & 4.6 \\
\hline Leg & 4 & 2.0 \\
\hline Neck & 4 & 2.0 \\
\hline Hand & 23 & 11.7 \\
\hline Arm & 25 & 12.7 \\
\hline Face & 86 & 43.7 \\
\hline Unspecified & 46 & 23.4 \\
\hline \multicolumn{3}{|c|}{ Lesion number $(n=127)$} \\
\hline 1 & 67 & 53.0 \\
\hline 2 or more & 60 & 47.0 \\
\hline \multicolumn{3}{|c|}{ Resident type ( $n=197)$} \\
\hline Slum & 6 & 3.0 \\
\hline Apartment & 113 & 57.0 \\
\hline Others & 5 & 2.5 \\
\hline Unspecified & 73 & 37.5 \\
\hline \multicolumn{3}{|c|}{$\begin{array}{l}\text { Animal shelters around residential area } \\
(n=121)\end{array}$} \\
\hline Present & 3 & 3.0 \\
\hline Non-present & 87 & 72.0 \\
\hline Unspecified & 31 & 25.0 \\
\hline \multicolumn{3}{|c|}{ Wetlands around residential area $(n=124)$} \\
\hline Present & 3 & 2.4 \\
\hline Non-present & 91 & 73.6 \\
\hline Unspecified & 30 & 24.0 \\
\hline \multicolumn{3}{|c|}{ People having CL lesion at the same household in the last year $(n=197)$} \\
\hline Yes & 45 & 23.0 \\
\hline No & 125 & 63.0 \\
\hline Unspecified & 27 & 14.0 \\
\hline
\end{tabular}




\begin{tabular}{|c|c|c|}
\hline \multicolumn{3}{|c|}{ People having CL scar at same household in the last year $(n=197)$} \\
\hline Yes & 9 & 4.6 \\
\hline No & 104 & 53.0 \\
\hline Unspecified & 84 & 42.4 \\
\hline \multicolumn{3}{|l|}{ Visit to Southeastern Anatolia region $(n=197)$} \\
\hline No & 95 & 48.0 \\
\hline Yes & 31 & 16.0 \\
\hline Unspecified & 71 & 36.0 \\
\hline \multicolumn{3}{|l|}{ Visited Southeastern Anatolia city $(n=31)$} \\
\hline Mus & 5 & 16.0 \\
\hline Sanlıurfa & 3 & 10.0 \\
\hline Mardin & 3 & 10.0 \\
\hline Gaziantep & 2 & 6.0 \\
\hline Mersin & 2 & 6.0 \\
\hline Other* & 16 & 52.0 \\
\hline \multicolumn{3}{|c|}{$\begin{array}{l}\text { The relationship between lesion onset and time to start living in Istanbul } \\
(n=197)\end{array}$} \\
\hline Lesion appeared before coming Istanbul & 74 & 38.0 \\
\hline Lesion appeared after coming Istanbul & 71 & 36.0 \\
\hline Unspecified & 52 & 26.0 \\
\hline \multicolumn{3}{|c|}{$\begin{array}{l}\text { The relationship between lesion onset and Southeastern Anatolia visit } \\
(n=31)\end{array}$} \\
\hline Lesion appeared after Southeastern Anatolia visit & 17 & 55.0 \\
\hline Lesion appeared before Southeastern Anatolia visit & 6 & 19.0 \\
\hline Unspecified & 8 & 26.0 \\
\hline
\end{tabular}

${ }^{\star}$ Batman, Bitlis, Corum, Diyarbakır, Elazıg, Amasya, Hatay, Irak, Kilis, Kahramanmaras, Osmaniye, Siirt, Tokat, Van

\section{Discussion}

For many years, $C L$ has been endemic in many Turkey provinces, especially hyperendemic in Sanlıurfa. Increase in the number of immigrants and travels also has increased the number of CL. According to the data of the General Directorate of Migration Management, Istanbul is the province where most Syrians live and under risk in terms of infectious diseases due to high population mobility (7).

In a study conducted by Culha et al. with $273 \mathrm{CL}$ patients in Hatay in 2014, female and male distribution was equal. Most cases were in $0-24$ age group (59\%) (8). In the study conducted by Karaosmanoglu et al. with 117 Syrian CL patients in Ankara in 2019 , percentage of female patients was $53 \%$ and the mean age was 16 years (9). In the study conducted by Korkmaz et al. with 635 patients in Gaziantep in 2015, 47\% of the patients were women and $66 \%$ were under 20 years of age (10). Similar to the literature, $47 \%$ of the cases in the present study were women and half were children under the age of 18 and the median age was
16. Children are vulnerable to this disease since they have not encountered parasites and not yet developed immunity against them compared to adults.

$C L$ lesions can be seen on either one or more region of body, mostly on the uncovered parts. In the study by Culha et al., more than one lesion was found in $14 \%$ of cases. The lesions were most commonly $(56 \%)$ found in head and neck region (8). In the study of Karaosmanoglu et al., $38 \%$ of the patients had two or three lesions (9). In 2016, Doni et al. screened 123 primary schools for two years in Sanlıurfa. The number of lesions in $\mathrm{CL}$ cases varied between one and 15, and the average number of lesions was $1.78 \pm 0.70$. It was determined that $38 \%$ of the cases had more than one lesion, $61.5 \%$ of the lesions were on face (11). In the present study, $53 \%$ of the cases had more than one lesion and $46 \%$ of lesions were on head and neck. Due to head and neck regions are mostly uncovered, the possibility of contact with the vector is high. The healing of CL lesion leaving an atrophic 
scar makes it important that CL lesions are seen most frequently on face. With the increasing number of Syrian immigrants in Turkey, the disease has gained an important impetus especially in Southeast Anatolia Region. Turkish immigrants from Southeast Anatolia and Syrian immigrants are an important source of $\mathrm{CL}$ in Istanbul. Southeast Anatolia visit was present in $16 \%$ of cases, and half of those who traveled to Southeast Anatolia had the lesion after this visit. In the study of Korkmaz et al., $89 \%$ of the cases were Syrian citizens and new infection centers were detected especially in villages close to the Syrian border (10). In the study of Salman et al. in Gaziantep/Nizip in 2014, $62(80 \%)$ of 77 patients diagnosed with CL were Syrian (12). A similar study was conducted by Inci et al. in Kahramanmaras with 110 patients and $69 \%$ of the patients were Syrian (13). In the present study, $77 \%$ of cases was Syrian. This rate, which is similar to the studies conducted in the border provinces, suggests that migration from Syria where the incidence of CL increased after the civil war, plays a part in the etiology of $C L$ in Istanbul. Such massive human movements can be important for not only the contamination of an infection agent and the spread of the disease but also the type of the this agent. It has been shown that in a study conducted by Zeyrek et al. with 14 patients in Sanliurfa in 2016; while the causative agent of $C L$ was known as Leishmania Tropica for many years in the region, Leishmania Infantum was isolated from five cases and these cases were reported as the first $L$. infantum cases reported in the Sanlıurfa province after Syrian immigrants were increased (14).

Living with a person infected with $\mathrm{CL}$ at same household is a risk factor for individuals since exposure to similar risk factors and circulating parasites due to untreated cases. Inci et al. reported that approximately $10 \%$ of patients' relatives were newly diagnosed with $\mathrm{CL}$. In the present study, the ratio of individuals living with an individual diagnosed with $\mathrm{CL}$ at the same household in the last year for $26 \%$ of the patients. This rate might be higher from the values in the literature because median number of people living at the same home was 6 six and we used a longer time definition as 'last year'. Animal shelters close to residential home is also a negative environmental factor for CL. Study of Korkmaz et al. in Gaziantep resulted that $36 \%$ of the patients had barns and animals close to their homes (10). In the present study, this rate was $3 \%$. Due to Istanbul's urban structure comparing with other regions, this etiologic factor might not come to fore.

$\mathrm{CL}$ is classified as acute, chronic and residual CL. Cases that have not healed over two years are classified as chronic CL and are observed in $5-10 \%$ of the cases. The lesions usually heal with 1-1.5 years with or without treatment, usually leaving a scar (14). In the present study, the median time first lesion to diagnosis was six months. The rate of chronic CL was 3.6\%. The availability of treatment services in Istanbul might cause lower rate of chronic CL and lesser time from first lesion to diagnosis.

\section{Limitations}

There are some limitations of the study. Due to language problems, there may be difficulties in transferring information from Syrian immigrants. Due to the two-thirds of the interviews were conducted with a person other than the patient, accurate information about the disease and affecting conditions may not be achieved.

\section{Conclusions}

The disease affects children as well as adults and the most frequently affected body area is the face. Most of the patients are Syrian immigrants. Household numbers are high and recent visits to areas where the disease is endemic was are dramatically standing out. Health Directorates of the

districts where Syrian immigrants live in Istanbul should screen all Syrian immigrants considering the majority of CL cases were Syrian. Improving living conditions of risky groups, especially Syrian citizens during summer months is essential. Drying of stagnant water areas, use of mosquito nets, 
wearing long-sleeved and closed clothes, eliminating the source of infection by diagnosis and effective treatment of $\mathrm{CL}$ are recommended control methods for $\mathrm{CL}$.

\section{References}

1. Reithinger $R$, Dujardin J-C, Louzir $H$, Pirmez C, Alexander B, Brooker S. Cutaneous leishmaniasis. Lancet Infect Dis. 2007;7(9):581-96.

2. World Health Organization. Leishmaniasis. Available from: https://www.who.int/ leishmaniasis/en/

3. World Health Organization. Report of the Interregional meeting on leishmaniasis among neighbouring endemic countries in the Eastern Mediterranean, African and European regions, Amman, Jordan, 23-25 September 2018. Available from: https://www.who.int/leishmaniasis/resour ces/who-em-ctd-081-e/en/

4. World Health Organization. Syrian Arab Republic. Available from: http:// www.who.int/leishmaniasis/burden/ Leishmaniasis_Syrian_Arab_Republic/en/

5. World Health Organization. Turkey. Available from: http://www.who.int/ leishmaniasis/burden/Leishmaniasis_Tur key/en/

6. T.C. Sağlık Bakanlığı. Bulaşıcı hastalıkların ihbar ve bildirim sistemi genelgesi. Ankara: Sağlık Bakanlığı; 2015. Available from: https://hsgm.saglik. gov.tr/tr/mevzuat/genelgeler.html

7. T.C. İ̧ İşleri Bakanlığı. 2016 Türkiye Göç Raporu. Ankara: İçişleri Bakanlığı Göç Idaresi Genel Müdürlüğü; 2016. Available from: https://www.goc.gov.tr/ kurumlar/goc.gov.tr/YillikGocRaporlari/2 016_yiik_goc_raporu_haziran.pdf

8. Çulha G, Doğramacı ÇA, Gülkan B, Savaş N. Cutaneous leishmaniasis and its status in Hatay province, Turkey. Turk Hij Den Biyol Derg. 2014;71(4):171-8.
9. Karaosmanoğlu N, Şahin $M$, Vahaboğlu G, Akbay G, Edgüer EY, Şahin T, et al. Cutaneous Leishmaniasis: Evaluation of 117 Syrian Immigrants. Turkiye Klinikleri J Med Sci. 2019;39(2):160-4.

10. Korkmaz S, Özgöztaşı O, Kayıran N. Gaziantep Üniversitesi Tıp Fakültesi Leishmaniasis Tanı ve Tedavi Merkezine Başvuran Kutanöz Leishmaniasis Olgularının Değerlendirilmesi. Turkiye Parazitol Derg. 2015;39:13-6.

11. Yentür Doni $N$, Gürses G, Dikme $R$, Şimşek Z, Muratoğlu M, Yildiz ZF. Şanlıurfa'da ilköğretim okullarında aktif tarama yöntemiyle kütanöz leyşmanyaz araştırması. Mikrobiyol Bul. 2016;50(4): 559-68.

12. Salman IS, Vural A, Unver A, Saçar $S$. Suriye iç savaşı sonrası Nizip'de kutanöz leyşmanyazis olguları. Mikrobiyol Bul. 2014;48:106-13.

13. Inci R, Ozturk P, Mulayim MK, Ozyurt K, Alatas ET, Inci MF. Effect of the Syrian civil war on prevalence of cutaneous leishmaniasis in southeastern anatolia, Turkey. Med Sci Mon Int Med J Exp Clin Res. 2015;21:2100.

14. Yıldız Zeyrek F, Töz S, Uluca N, Doni N, Toprak Ş, Özbel Y. Şanlıurfa'da Leishmania infantum'un etken olduğu kutanöz leyşmanyazis (şark çıbanı) olguları. Mikrobiyol Bul. 2020;54(4): 647-56.

15. Gürel MS, Yeşilova Y, Ölgen MK, Özbel Y. Türkiye'de kutanöz leishmaniasisin durumu. Turkiye Parazitol Derg. 2012;36:121-9. 